\title{
Anatomical properties of Eucalyptus grandis wood and transition age between the juvenile and mature woods
}

\author{
G. P. de M. Palermo ${ }^{1}$ J. V. de F. Latorraca ${ }^{1}$ - A. M. de Carvalho ${ }^{1}$. \\ F. W. Calonego ${ }^{2}$ E. T. D. Severo ${ }^{2}$
}

Received: 5 June 2014/Published online: 7 July 2015

(c) Springer-Verlag Berlin Heidelberg 2015

\begin{abstract}
The present study is aimed at evaluating the anatomical characteristics of Eucalyptus grandis wood and the transition age between the juvenile and mature woods. Four trees of 23-year-old E. grandis were used. The juvenile, transition and mature wood zones were found by fiber length measurement from the pith to the bark. Samples were taken from juvenile wood, transition wood and mature wood and the anatomical properties of the wood were determined. The results showed that: (1) the fiber length, cell wall thickness, slenderness ratio, cell wall fraction and tangential vessel diameter increase from pith to bark; (2) fibers, axial parenchyma, ray parenchyma cells and vessels are equally distributed from pith to bark; (3) the transition zone between juvenile and mature wood occurs between the age of 8 and 13 years.
\end{abstract}

\section{Introduction}

In general, the heterogeneity of wood causes a large deal of inconvenience to the fabrication and processing industries that employ the wood. According to Cruz et al. (2003), knowledge of the various types of wood within a log may allow obtaining more uniform lots to meet more specific needs.

F. W. Calonego

fwcalonego@ig.com.br

1 Department of Forestry Products, Institute Forests, UFRRJ, BR 456, Km 7, P.O. Box 74527, CEP: 23851-970 Seropédica, RJ, Brazil

2 Department of Forest Science, Faculty of Agricultural Sciences, UNESP, Fazenda Experimental Lageado, P.O. Box 237, CEP: 18603-970 Botucatu, SP, Brazil
The material's chemical and physical-mechanical discontinuity occurs owing to several factors, such as species, silviculture, and particularly the wood anatomy. Juvenile wood can be defined as being close to the pith and, technologically, it differs from mature wood on account of several properties (Bao et al. 2001; Bendtsen 1978; Calonego et al. 2005; Ferreira et al. 2011; Palermo et al. 2011, 2013; Zobel and Van Buijtenen 1989; Zobel and Sprague 1998).

There are numerous hypotheses about the cause of juvenile wood. It is controlled by production of auxin in the tree crown and results from close proximity to the foliage. Thus, the most accepted concept is that it is directly related to the age of the cambium that determines whether juvenile, transition or mature wood is formed (Zobel and Van Buijtenen 1989; Zobel and Sprague 1998).

The length and wall thickness of fibers in juvenile wood obtained from 26-year-old Corymbia citriodora were $0.995 \mathrm{~mm}$ and $3.59 \mu \mathrm{m}$, whereas in mature wood, they were $1.224 \mathrm{~mm}$ and $3.73 \mu \mathrm{m}$, respectively (Bao et al. 2001). Calonego et al. (2005) demonstrated that 32-yearold trees of the above-mentioned species produce juvenile and mature wood with respective fiber lengths of $0.943-1.140 \mathrm{~mm}$ and $1.186-1.350 \mathrm{~mm}$. The juvenile wood of 28-year-old E. grandis has $1.009 \mathrm{~mm}$, whereas the mature wood has $1.145 \mathrm{~mm}$ (Leonello et al. 2008).

Brasil and Ferreira (1972) concluded that the juvenile wood of 16-year-old E. grandis trees has $0.836 \mathrm{~mm}, 17.00$, $9.75,3.88 \mu \mathrm{m}, 0.435 \mathrm{~g} / \mathrm{cm}^{3}$ and $325.6 \mu \mathrm{m}$ of fiber length, fiber diameter, lumen diameter, cell wall thickness, basic density and vessel length, whereas the mature wood has $1.276 \mathrm{~mm}, \quad 17.25, \quad 7.75, \quad 5.00 \mu \mathrm{m}, \quad 0.574 \mathrm{~g} / \mathrm{cm}^{3}$ and $400.4 \mu \mathrm{m}$, respectively.

Even so, the juvenile and mature wood regions were determined according to several authors by the 
densitometric profile, microfibrillar angles and fiber lengths (Calonego et al. 2005; Leonello et al. 2008; Palermo et al. 2011, 2013; Taylor 1979; Zobel and Van Buijtenen 1989).

Calonego et al. (2005) showed that the juvenile wood of C. citriodora occurs between 40 and $55 \mathrm{~mm}$ from the pith. Leonello et al. (2008) concluded that the juvenile wood of E. grandis is confined up to $150 \mathrm{~mm}$ from the pith. Moreover, these authors did not perform studies to determine the transitional age of these types of wood. Nevertheless, Ramos et al. (2011) showed that the transition zone between juvenile and mature wood of E. grandis occurs between the 5 th and 11 th year.

The anatomical characterization of Pinus elliottii var. elliottii showed that the juvenile wood is confined between 145 and $185 \mathrm{~mm}$ from the pith that corresponds to formed wood of up to 21-year-old (Palermo et al. 2011).

Although several studies have been carried out on the juvenile and mature wood of softwoods, there is little knowledge of hardwoods (Evans et al. 2000; Bao et al. 2001; Calonego et al. 2005), and few comparisons have been made among the properties from the pith up to bark of the eucalyptus.

Therefore, the present study is aimed at evaluating anatomical characteristics of E. grandis wood and the transition age between the juvenile and mature woods.

\section{Materials and methods}

\subsection{Collection of material}

This study used the wood of four trees of 23-year-old $E$. grandis Hill ex Maiden from the Quinvale Company located in Barra do Piraí (22 $43^{\prime} 23^{\prime \prime}$ south latitude and $44^{\circ} 08^{\prime} 08^{\prime \prime}$ west longitude), Rio de Janeiro, Brazil.

The trees were felled and disks with a thickness of $100-\mathrm{mm}$ were sectioned in the stem at breast height $(1.30 \mathrm{~m})$. Samples measuring $10 \times 10 \times 100 \mathrm{~mm}^{3}$ in length $\times$ width $\times$ height were taken from the pith to the bark, as shown in Fig. 1.

Half of each sample was used to produce macerated sections and the other half was used to obtain histological sections. The boundaries of the juvenile and mature wood regions were determined through visual analysis of graphs obtained from the fiber length average by standards of the International Association of Wood Anatomists Committee (1989), and as performed by Zobel and Van Buijtenen (1989), Calonego et al. (2005) and Ferreira et al. (2011). Thus, these samples were separated into three regions: juvenile, transition and mature wood.

Later, the anatomical characteristics were dissociated by the method of Franklin (Sass 1951), and histology slides were produced on glass slides with glycerine and safranin (1\%) according to the procedure used by several authors (e.g., Leonello et al. 2008 and Palermo et al. 2013).

\subsection{Anatomical analysis of $E$. grandis wood}

Measurements of anatomical characteristics were made in the Laboratory of Anatomy and Quality of Wood at the Federal Rural University of Rio de Janeiro, RJ, Brazil, following the standard presented by IAWA Committee (1989) and recommendations of Foelkel and Barrichello (1975).

The following anatomical characteristics of each sample were measured by "Cell F" software: vessels (tangential diameter and length), fibers (length, diameter, lumen diameter, cell wall thickness, cell wall fraction and slenderness ratio). The number of replications used to determine the dimensions of each anatomical characteristic is shown in Table 1. The percentage of each anatomical characteristic in the wood (fiber, vessel, and axial and ray parenchyma cells) was also determined.

For the evaluation of anatomical properties, an analysis of variance with $95 \%$ probability taking into account the type of wood and the Tukey test at $5 \%$ significance for the comparison of the means were made.
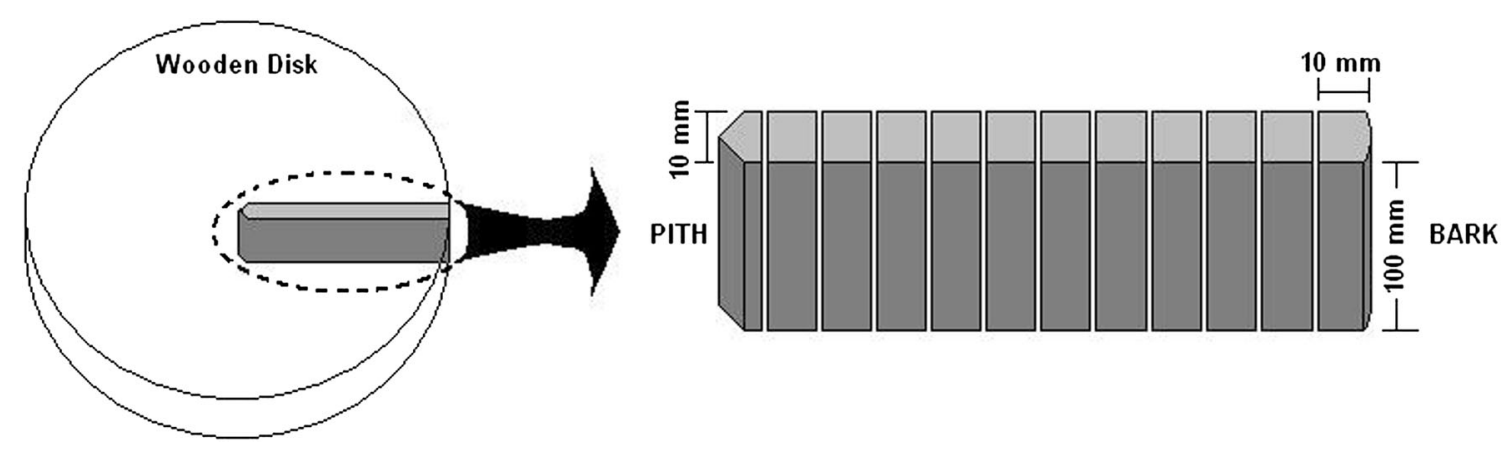

Fig. 1 Scheme for preparing the wood samples 
Table 1 Parameters used in the anatomical properties tests of E. grandis wood

\begin{tabular}{lllc}
\hline Parameters & Units & Measuring site & $\begin{array}{c}\text { Number of replications } \\
\text { by type of wood }\end{array}$ \\
\hline Fiber length (L) & $\mathrm{mm}$ & Macerated & 25 \\
Fiber diameter or fiber width (D or W) & $\mu \mathrm{m}$ & Macerated & 25 \\
Fiber lumen diameter (d) & $\mu \mathrm{m}$ & Macerated & 25 \\
Fiber wall thickness (e) & $\mu \mathrm{m}$ & Macerated & 25 \\
Wall fraction (D - d/D) & Dimensionless & Macerated & 25 \\
Fiber slenderness ratio (L/D) & Dimensionless & Macerated & 25 \\
Vessel length & $\mu \mathrm{m}$ & Macerated & 25 \\
Vessel tangential diameter & $\mu \mathrm{m}$ & Transverse sections & 25 \\
Fiber percentage & $\%$ & Transverse sections & 1 \\
Axial parenchyma percentage & $\%$ & Transverse sections & 1 \\
Ray percentage & $\%$ & Transverse sections & 1 \\
Vessel percentage & $\%$ & Transverse sections & 1 \\
\hline
\end{tabular}

\subsection{Determination of age transition from juvenile wood to mature wood}

The relationship between fiber length and radial distance was evaluated using polynomial regression, by taking into account the observed tendency of data. The models of the regression curves with $95 \%$ probability were adjusted.

The boundaries of the juvenile, transition and mature wood regions were determined from the behavior of the fibers length at pith to bark direction, as recommended by Zobel and Van Buijtenen (1989), Calonego et al. (2005), Ferreira et al. (2011) and Palermo et al. (2011, 2013).

The age of transition between juvenile and mature wood was determined through measurements of growth rings by $\mathrm{X}$-ray microdensitometry technique, according to Oliveira et al. (2012). An annual growth ring is regarded as the period for the formation of two consecutive peaks of high density, as shown by Ferraz (1983). Thus, by both demarcation of annual ring as well as annual growth increment the exact position of each sample in radial section was identified and consequently the year of their formation.

\section{Results and discussion}

\subsection{Anatomical characterization of $E$. grandis wood}

The parameters that characterize the anatomical properties of E. grandis wood are shown in Table 2.

It can be seen that there was a significant difference in the fiber length, cell wall thickness, cell wall fraction, fiber slenderness ratio and the vessel tangential diameter between the juvenile and mature wood regions of the stem.
These results are similar to those cited by Bao et al. (2001), who characterized the anatomical properties of $C$. citriodora, as well as those reported by Brasil and Ferreira (1972). In addition, these behaviors were similar to those presented by Calonego et al. (2005), Leonello et al. (2008), Ferreira et al. (2011) and Palermo et al. (2011, 2013).

Even according to Zobel and Sprague (1998) and Zobel and Van Buijtenen (1989), the fiber length, cell diameter and wall thickness of diffuse-porous species, among them the eucalyptus, are low at the pith, increase outward and tend to plateau in the mature wood. According to Zobel and Van Buijtenen (1989), the cambial initial cells increase in size with age of the secondary meristem and become more stable with the maturity of cambium.

Moreover, Table 2 shows that the percentage of each anatomical characteristic in the wood (fiber, vessel, and axial and ray parenchyma cells) did not reveal significant differences from the pith up to the bark of the E. grandis stem.

The fiber, vessels, and axial and ray parenchyma percentage of juvenile wood from E. grandis were 54.4, 17.2, 14.4 , and $14.0 \%$, respectively. In the transition wood, these anatomical elements were 58.7, 15.4, 13.4, and $12.4 \%$, whereas the mature wood presents $51.8,15.8,15.6$, and $16.8 \%$, in the respective characteristics. These behaviors are similar to those reported by Bao et al. (2001).

In addition, these results are similar to those found by Queiroz (2002), where the wood of smaller density $E$. grandis $\times$ urophylla showed fibers, vessels and parenchyma percentage of $69.3,13.6$ and $17.1 \%$, whereas in the wood of higher density clone, it was $66.5,19.2$, and $14.3 \%$, respectively.

The dimension of the fibers, the tissue composition of wood by fibers, vessels, radial and axial parenchyma can predict a specific property of the wood. For example, 
Table 2 Anatomical characteristics from the pith up to bark of E. grandis stem

\begin{tabular}{|c|c|c|c|}
\hline \multirow[t]{2}{*}{ Anatomical characteristics } & \multicolumn{3}{|l|}{ Type of wood } \\
\hline & Juvenile & Transition & Mature \\
\hline Fiber length (L) (mm) & $0.986^{\mathrm{a}}(0.125)$ & $1.088^{\mathrm{b}}(0.0613)$ & $1.110^{\mathrm{b}}(0.0982)$ \\
\hline Fiber diameter or fiber width $(\mathrm{D}$ or $\mathrm{W})(\mu \mathrm{m})$ & $21.04^{\mathrm{a}}(2.235)$ & $21.57^{\mathrm{a}}(2.357)$ & $22.05^{\mathrm{a}}(2.772)$ \\
\hline Fiber lumen diameter $(\mathrm{d})(\mu \mathrm{m})$ & $14.01^{\mathrm{a}}(2.199)$ & $14.29^{\mathrm{a}}(2.087)$ & $14.14^{\mathrm{a}}(3.395)$ \\
\hline Fiber wall thickness $(e)(\mu \mathrm{m})$ & $3.51^{\mathrm{a}}(0.818)$ & $3.62^{\mathrm{ab}}(0.519)$ & $3.93^{\mathrm{b}}(0.664)$ \\
\hline Wall fraction (D - d/D) (dimensionless) & $0.445^{\mathrm{a}}(0.230)$ & $0.438^{\mathrm{ab}}(0.211)$ & $0.579^{\mathrm{b}}(0.227)$ \\
\hline Fiber slenderness ratio (L/D) (dimensionless) & $47.10^{\mathrm{a}}(5.609)$ & $50.96^{\mathrm{a}}(5.438)$ & $51.24^{\mathrm{b}}(8.656)$ \\
\hline Vessel length $(\mu \mathrm{m})$ & $436.67^{\mathrm{a}}(94.200)$ & $429.18^{\mathrm{a}}(67.420)$ & $480.43^{\mathrm{a}}(88.643)$ \\
\hline Vessel tangential diameter $(\mu \mathrm{m})$ & $124.08^{\mathrm{a}}(30.644)$ & $134.77^{\mathrm{ab}}(29.527)$ & $140.53^{\mathrm{b}}(22.524)$ \\
\hline Fiber percentage & $54.4^{\mathrm{a}}(14.907)$ & $58.7^{\mathrm{a}}(15.263)$ & $51.8^{\mathrm{a}}(15.126)$ \\
\hline Axial parenchyma percentage & $14.4^{\mathrm{a}}(7.445)$ & $13.4^{\mathrm{a}}(6.211)$ & $15.6^{\mathrm{a}}(7.239)$ \\
\hline Ray percentage & $14.0^{\mathrm{a}}(5.526)$ & $12.4^{\mathrm{a}}(7.225)$ & $16.8^{\mathrm{a}}(8.536)$ \\
\hline Vessel percentage & $17.2^{\mathrm{a}}(9.579)$ & $15.4^{\mathrm{a}}(5.739)$ & $15.8^{\mathrm{a}}(5.806)$ \\
\hline
\end{tabular}

Number in brackets—standard deviation; different letters-significant difference by Tukey test at probability $95 \%$; same letters-non-significant difference increasing the density of the wood depends on the increase in cell wall thickness of fibers or an increase in the proportion of fibers at the proportion of vessels.

As shown in Table 2, the wall thickness, fraction and wall slenderness ratio increased from pith to bark.

This behavior was similar to that found by several authors, among them Brasil and Ferreira (1972) and Sette Junior et al. (2009). It is noted that the increase of this parameter increases the resistance of wood to friction during cutting or thinning and improves the quality of the machined surface in this region, which is advantageous if this timber is used for the production of higher value added.

\subsection{Age transition from juvenile wood to mature wood}

Figure 2 shows the variation of fiber length from the pith to bark of $E$. grandis stem and the delimitation of juvenile and mature wood zones.

The resulting curves from the average fiber length, measured in " $\mathrm{mm}$ ", in the radial direction, for each tree can be seen. For the studied trees, the fiber length showed a high, nearly linear increase until $60-70 \mathrm{~mm}$ after the pith, according to linear regression curves.

From the radial distance of $100-110 \mathrm{~mm}$ to the periphery of the stem, the increase rate in fiber length decreased, tending to be more stable and almost a constant value. This behavior is similar to the one described and observed by several authors, such as Calonego et al. (2005), Leonello et al. (2008), Ferreira et al. (2011), Palermo et al. (2011, 2013), Zobel and Van Buijtenen (1989) and Zobel and Sprague (1998). However, these authors did not perform studies to determine the transitional age of these types of wood.

Moreover, based on the radial density analysis by X-ray densitometry, the transition age between juvenile and mature wood of E. grandis is shown in Table 3. The transition zone between juvenile and mature wood occurs between the 8th and 13th year.

These results are consistent with the literature, showing that this tendency is a characteristic of juvenile wood formation in the tree's early years (Brasil and Ferreira 1972; Calonego et al. 2005; Leonello et al. 2008; Ferreira et al. 2011; Palermo et al. 2011, 2013; Zobel and Van Buijtenen 1989).

These results were not equal to those shown by Ramos et al. (2011) who studied E. grandis and concluded that the transition zone between juvenile and mature wood occurs between the 5th and 11th year. Furthermore, other factors may influence this variation in the transition age from juvenile and mature woods. Some authors (Bendtsen 1978, Zobel and Sprague 1998 and Loo et al. 1985) reported that the age of transition from juvenile to mature wood varies considerably among trees, region of forest stands, seed provenance, local environmental conditions, as well as genetic factors. It can also differ due to the property of the wood used to delimit the transition zone between the types of wood.

\section{Conclusion}

According to the results presented for $E$. grandis, it is possible to conclude that: (a) the fiber length, cell wall thickness, slenderness ratio, cell wall fraction, and 


\section{Tree 1}

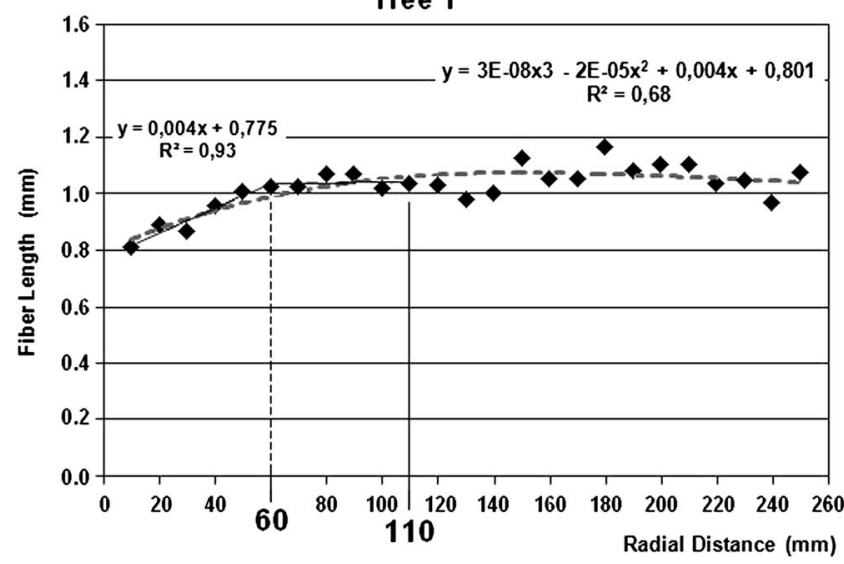

Tree 3

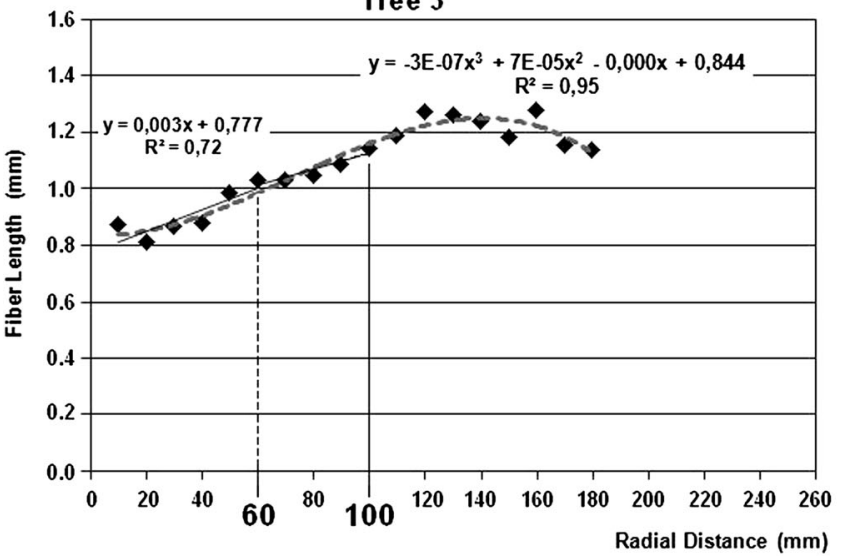

Tree 2

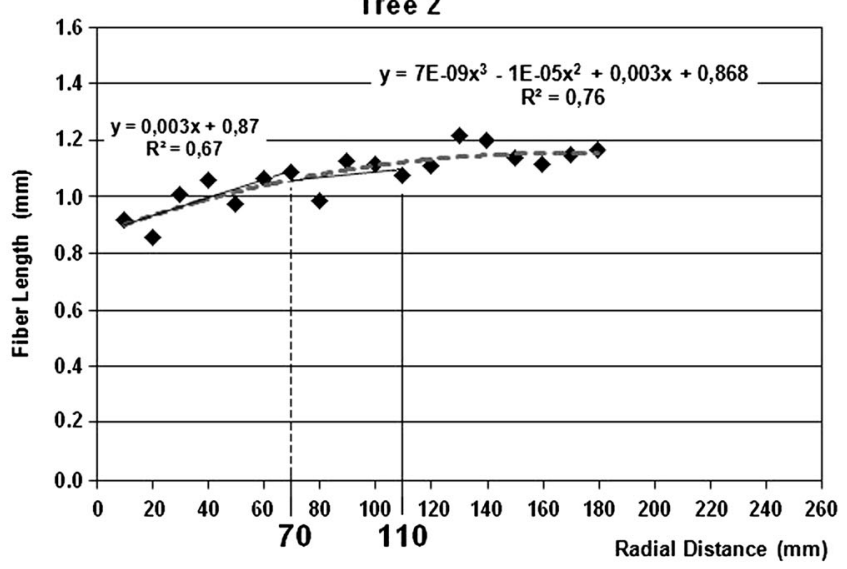

Tree 4

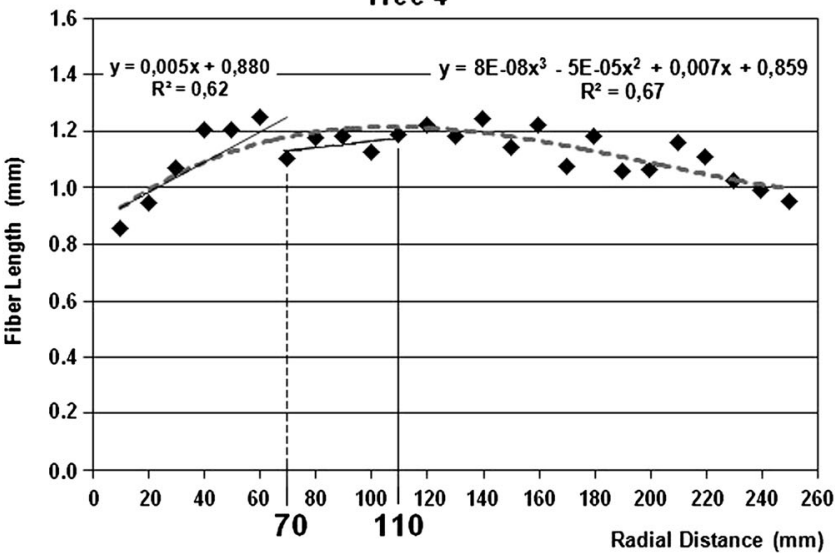

Fig. 2 Demarcation of juvenile wood (up to the dashed line), transition wood (between dashed and solid lines) and mature wood (as from the solid line) from E. grandis

Table 3 Transition age from juvenile wood to mature wood of E. grandis

\begin{tabular}{lllllll}
\hline Tree & $\begin{array}{l}\text { Juvenile wood } \\
(\mathrm{mm})\end{array}$ & Age (years) & $\begin{array}{l}\text { Transition } \\
\text { wood (mm) }\end{array}$ & $\begin{array}{l}\text { Age } \\
\text { (years) }\end{array}$ & $\begin{array}{l}\text { Mature } \\
\text { wood (mm) }\end{array}$ & $\begin{array}{l}\text { Age } \\
(\text { years })\end{array}$ \\
\hline 1 & $0-60$ & 7 & $60-110$ & $8-11$ & $110-250$ & 11 \\
2 & $0-70$ & 10 & $70-110$ & $10-16$ & $110-180$ & 16 \\
3 & $0-60$ & 7 & $60-100$ & $7-12$ & $100-180$ & 12 \\
4 & $0-70$ & 9 & $70-110$ & $9-13$ & $110-290$ & 13 \\
Average & & 8.25 years-old or 8 years & & & \\
and 3 months old & & & & 2.2 \\
Standard deviation & & 1.5 & & & \\
\hline
\end{tabular}

tangential vessel diameter increase from pith to bark; (b) fibers, axial parenchyma, ray parenchyma cells, and vessels are equally distributed from pith to bark; (c) the transition zone between juvenile and mature wood occurs between the 8 th and 13 th year.

Acknowledgments The authors thank the National Council of Technological and Scientific Development (CNPq) and Research Assistance Foundation from Rio de Janeiro (FAPERJ) by scholarship of "Young Talents" Project.

\section{References}

Bao FC, Jiang ZH, Jiang XM, Lu XX, Luo XQ, Zhang SY (2001) Differences in wood properties between juvenile wood and mature wood in 10 species grown in China. Wood Sci Technol $35: 363-375$

Bendtsen B (1978) Properties of wood from improved and intensively managed trees. For Prod J 28(10):61-72

Brasil MAM, Ferreira M (1972) Change in basic density and characteristics of fiber in Eucalyptus grandis Hill ex Maiden at diameter at breast height. IPEF 5:81-90 (in Portuguese) 
Calonego FW, Severo ETD, Assi PP (2005) Fiber length measurement from the determination of juvenile wood in Eucalyptus citriodora. Sci For 68:113-121 (in Portuguese)

Committee IAWA (1989) List of microscopic features for hardwood identification. IAWA Bull 10:219-312

Cruz CR, Lima JT, Muniz GIB (2003) Within trees and between clones variations of the wood physical and mechanical properties of Eucalyptus hybrids. Sci For 64:33-47

Evans JW II, Senft JF, Green DW (2000) Juvenile wood effect in red alder: analysis of physical and mechanical data to delineate juvenile and mature wood zones. For Prod J 50:75-87

Ferraz ESB (1983) Growth ring and climate in Eucalyptus. Silvicultura 8(32):821-822 (in Portuguese)

Ferreira AL, Severo ETD, Calonego FW (2011) Determination of fiber length and juvenile and mature wood zones from Hevea brasiliensis trees grown in Brazil. Eur J Wood Prod 69:659-662

Foelkel CEB, Barrichello LEG (1975) Evaluation of wood for pulp production through its structural features: a special reference to the genus Eucalyptus. In: Proceedings of the Seminário de Integração Floresta-Indústria, IPEF, Piracicaba, Brazil, p 5-33 (in Portuguese)

Leonello EC, Lara-Palma HA, Ballarin AW (2008) Determination of juvenile and mature woods of Eucalyptus grandis in São Paulo, Brazil. Rev For Venez 52:93-98 (in Portuguese)

Loo JA, Tauer CG, McNew RW (1985) Genetic variation in the time of transition from juvenile to mature wood in Loblolly Pine (Pinus taeda L.). Silvae Genet 34(1):14-19

Oliveira BRU, Latorraca JVF, Filho MT, Palermo GPM, Carvalho AM, Pastro MS (2012) X-ray microdensitometry applied to determination of wood density variation of Eucalyptus grandis W. Hill trees. Sci For 40(93):103-112
Palermo GPM, Latorraca JVF, Severo ETD, Rezende MA, Nascimento AM (2011) Juvenile and mature wood transition of Pinus elliottii from anatomical and physical properties. In: Proceedings of the Congreso Ibero-Latinoamericano de la madera en la construcción, CIMAD 11, Coimbra, Portugal, p 9 (in Portuguese)

Palermo GPM, Latorraca JVF, Severo ETD, Nascimento AM, Rezende MA (2013) Delimitation the juvenile and mature wood of Pinus elliottii Engelm. Rev Árvore 37(1):191-200 (in Portuguese)

Queiroz SCS (2002) Effect of chemical and anatomical characteristics on wood basic density and pulp quality of Eucalyptus grandis $\times$ urophylla hybrid clones. Thesis, Federal University of Viçosa (in Portuguese)

Ramos LMA, Latorraca JVF, Pastro MS, Souza MT, Garcia RA, Carvalho AM (2011) Radial variation of wood anatomical characters of Eucalyptus grandis W. Hill Ex Maiden and age of transition between adult and juvenile Wood. Scientia Forestalis 39(92):411-418

Sass JE (1951) Botanical microtechnique, 2nd edn. State College Press, Iowa

Sette Júnior CR, Tomazello Filho M, Lousada JL, Laclau JP (2009) Effect of nitrogen and sewage sludge application on juvenile wood characteristics of Eucalyptus grandis trees. Cerne 15(3):303-312

Taylor FW (1979) Property variation within stems of selected hardwoods growing in the mid-south. Wood Sci 11:193-199

Zobel BJ, Sprague JR (1998) Juvenile wood in forest trees. Springer, New York

Zobel BJ, Van Buijtenen JP (1989) Wood variation: its causes and control. Springer, New York 